\title{
Green Hotel and Its Implementation in Indonesia (Case Study: Aston Hotel \& Resort Bogor, Neo Hotel, and Fave Hotel)
}

\author{
Yustisia Pasfatima Mbulu ${ }^{1}$, I Made Adhi Gunadi ${ }^{2}$ \\ ${ }^{1,2}$ Faculty of Tourism Universitas Pancasila, Jakarta, Indonesia \\ ${ }^{1}$ yustisiapm@gmail.com, and ${ }^{2}$ aradha.m@gmail.com
}

\begin{abstract}
This study aimed to examine the policy of Green Hotel and its implementation at Aston Hotel \& Resort Bogor, as well as to analyze the application of green concept hotel at Aston Hotel \& Resort Bogor to its own hotel network management, such as Neo Hotel and Fave Hotel. This research used qualitative description method with a case study approach. The result of this research showed that Aston Hotel \& Resort Bogor has implemented Green Hotel policy made by the Ministry of Tourism of the Republic of Indonesia. There are fourteen aspects of Green Hotel's policy and out of the fourteen aspects, Aston Hotel \& Resort Bogor has implemented energy efficiency policy, water efficiency policy, room ventilation, emission and noise quality policy, waste management policies, appropriate land use policy, human resource quality policy through training, "Green Hotel" implementation program policy for staff-guest-society, occupational health and safety policy, hygiene and sanitation policy especially food and beverage department. However, there are aspects, which have not been done by Aston Hotel \& Resort Bogor, so they still need to be done to meet the Green Hotel concept. The implementation of green hotel concept policy at Aston Hotel \& Resort Bogor to hotel network management such as Neo Hotel Neo Hotel, and Fave Hotel, goes through several planned activities. These steps are provided to lead the hotel forming and establishing the Green Hotel concept that aims to environmental awareness and sustainability.
\end{abstract}

Keywords-Police, Green Hotel, and Implementation.

\section{INTRODUCTION}

Rapid development in Indonesia's tourism has grown hotel accommodation industry everywhere that it opens opportunities to invest in hotel industry. Hospitality and tourism are related to each other because the growth of hotel industry cannot be separated from the development of tourisms sector in Indonesia. On the other hand, tourism will not be able to grow without supporting of hotel industry, which accommodates the inbound and outbound tourists in travel (Erlangga et.al., 2016).

The Central Bureau of Statistics notes that the number of foreign tourist arrivals to Indonesia has been increasing since 2006. A total of 8.8 million foreign tourists have visited Indonesia in 2013, growing 9.4\% compared to 2012. The high tourist visit put Indonesia in Asia's third place in the field of hospitality development and investment. According to data released by STR Global, in 2014 Indonesia built 149 hotels with a total of 23,778 rooms or $7.7 \%$ of the total 2,063 hotels throughout Asia Pacific region. The number of hotel developments in Indonesia is the third largest after China and India.

By this statistical data, the Indonesian government, especially the Ministry of Tourism, applies Green Hotel concepts to hotels in Indonesia. The Ministry of Tourism hopes the hotel with green concept or Green Hotel does not only chase profit but also concern about economic and environmental sustainability in the future.

\section{LITERATURE REVIEW}

According to Ministry of Tourism in Indonesia (2016), building a culture and realizing a hotel with environmental concept require two-way communication among staff, managers, residents, and stakeholders involved. In the implementation, cooperation is needed on all levels of hotel organization to majorly impact to the goal objectives -to make hotel facilities and supports to get more competitive following the emerging market trends. 
Meanwhile, according to International Ecotourism Society, more than two-thirds of tourists from America and Australia, also over $90 \%$ of tourists from the UK, consider that environmental protection and support to local communities are part of hotel responsibility (Rahmafitria,F., 2014). A large number of business tours, conventions, and travelers have preferred sustainable and eco-friendly destinations and attractions (Sinangjoyo, N.J., 2014; Syahriyah, D.R., 2016). There is even a wave of suggestions from various governments around the world that require their employees to stay or to hold meetings and conventions in a "Green Hotel" (Anggita, D. et.al., 2016). Surely sooner or later, the world will tend to prefer the development and management of a sustainable hotel and this trend will also affect the tourism and hospitality industry in Indonesia.

In responding such trend, the Ministry of Tourism and the Creative Economy of Indonesia took the initiative to prepare and improve the capacity of hotel industry in Indonesia through education and provision of other instruments that can systematically and comprehensively encourage the transformation towards a sustainable and environmentally friendly industry.

In Indonesia, government support to entrepreneurs and hotel managers who have applied the environmentally friendly principles is shown by giving the award of Green Hotel Award which can be a pass to join and to be nominated in ASEAN Green Hotel Award (2013).

Aston Hotel \& Resort Bogor was one of hotels which got Green Hotel Awards in 2015. This hotel is a 4-star hotel management chain from Archipelago International. Archipelago International also has Grand Aston for 5 stars, Quest Hotel for 3 stars, Neo Hotel for 3+ stars, and Fave Hotel for 2 stars.

This study aims to examine the policy of Green Hotel and its implementation of Aston Hotel \& Resort Bogor, as well as to analyze the application of green concept hotel at Aston Hotel \& Resort Bogor to its own hotel network management, such as Neo Hotel and Fave Hotel. The conceptual framework is described in figure 1 .

\section{METHODS}

The method used in this research is descriptive qualitative method. The type of descriptive qualitative research used is case study approach. This study focuses intensively on one particular object that studies it as a case. Case study data can be obtained from all related parties, or the data in this study are collected from various sources (Nawawi, 2003). As a case study, the data collected come from various sources and the results of this study apply only to the cases investigated. Further Arikunto (1986) argued that the case study method as one type of descriptive approach is a detailed research conducted in detail and exhaustively against a particular organism (individual), institution or symptom with a small area or subject.

The object of the research is Aston Hotel \& Resort Bogor, a variable which has the concept of Green Hotel. Data collection was obtained through observation, interview, and documentation analysis. 
Policies related to hotels with environmental concept

(According to the Ministry of Tourism of the Republic of Indonesia)

1. Energy efficiency policies (including sources and their use)

2. Water efficiency policies (including consumption, quality and handling of liquid waste)

3. Policies on controlling the quality of rooms' air conditioning, emission and noise.

4. Hygiene and sanitation policy, especially in food and beverage management

5. Policy on procurement/expenditure on building materials that are environmentally friendly

6. Policy on procurement/expenditure on hotel operational materials that are environmentally friendly

7. Waste management policy (reuse, recycle, reduce, replace, renewable and composting)

8. Hazardous and toxic waste management policy (B3 waste), including its use, storage and disposal.

9. Policies in managing renovation or repair of hotel facilities to ensure no bad impact on the environment.

10. Land use policy for any available land according to the land use regulation

11. Policy in improving the quality of human resources, through training according to the competencies required in the fields of energy, water, materials, air, waste, etc

12. Policies in implementing "Green Hotel" program for hotel staff, guests, and community.

13. Policies related to social, economic and cultural aspects in society

14. Occupational safety and health policy

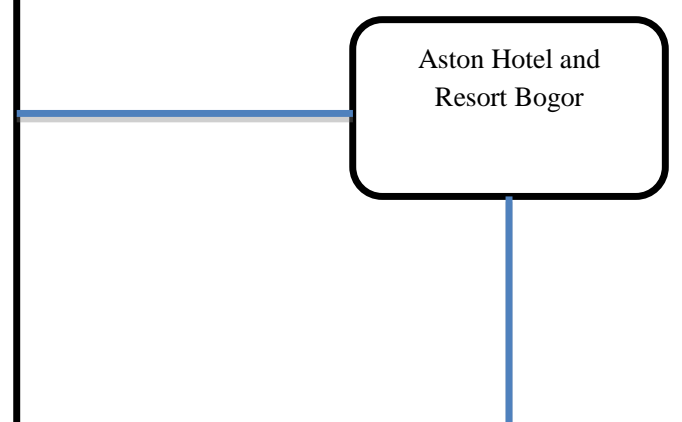

14.

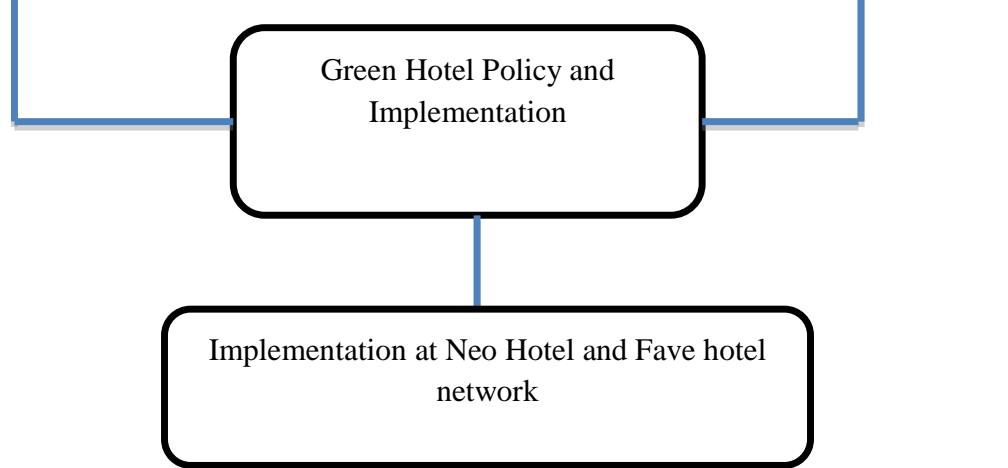

Fig. 1. Conceptual Frameworks

\section{RESULT AND DISCUSSION}

The tourism industry, especially hotel industry, plays an important role in suppressing the rate of global warming which is resulted from the increasing of carbon emissions generated by the use of land, 
energy, water, and air. One of the steps that can be done is from the hotel building sector, whose growth also increases from time to time. If the movement of "Green Hotel" can be run, it will improve the quality in tourism sector.

According to ASEAN Tourism Standard, Green Hotel is an environmentally friendly hotel and practice energy saving. The highest cost in the hospitality sector is the energy section which is used for electricity, fuel and water. Based on data from United Nations World Tourism Organization (UNWTO), hotels and similar type of accommodations generate $2 \%$ of $5 \%$ of $\mathrm{CO} 2$ emissions generated by the global tourism sector. The hotel sector is indeed the biggest driver of the tourism industry in absorbing labors and earning money; however, the hotel sector is also the sector with the highest energy use so that hotel industry should strongly consider its sustainable development program.

In practicing Green Hotel, guests are expected not to wash towels or replace sheets daily, to use door locks that can turn on and off lights automatically, to use dispensers for shampoo and soap, or to water the plants with used water. They are some of the hotel efforts to save energy and protect the environment. Hotels that have such an eco-friendly program is referred to as Green Hotel in ASEAN.

Indonesian Ministry of Tourism presented Indonesia Green Hotel Awards In 2015 to 20 hotels. From the selected hotels, 10 best hotels were selected to represent Indonesia to ASEAN level. Green Hotel's award-winning hotels should be proud and encouraged to promote their achievements. One of them was Aston Hotel and Resort Hotel.

\section{A. Reviewing the hotel's green policy and its implementation: Aston Hotel \& Resort Bogor}

From the beginning, Aston hotel \& resort Bogor has been designed to become Green Hotel / Green Building. The situation of the hotel is described in figure 2 .

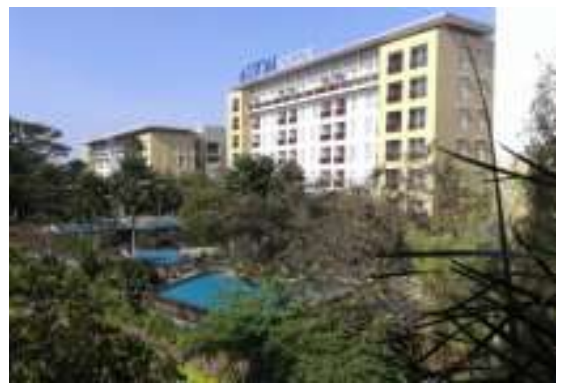

Fig. 2 Aston Bogor

Source: Hotel Aston Bogor

Energy efficiency measures are being pursued by the hospitality sector that wants to start and support good initiatives such as through energy management. Planning an energy management program from the beginning will help maintain the level of profitability of a hotel. It will always be aligned and easily adjusted to the level of comfort and satisfaction of the targeted hotel residents. 

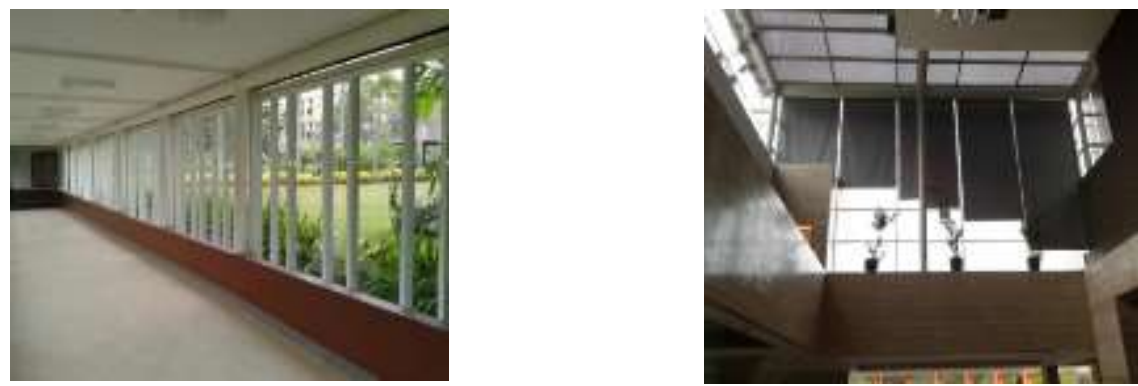

Fig. 3 Saving Energy by Solar Lighting Source: Hotel Aston Bogor

In addition to maximize solar lighting, energy efficiency policies also maximize the automatic switch and use the automatic timer. The purpose of using the automatic switch can regulate all energy usage for guests who are staying at the hotel that is described in figure 4.
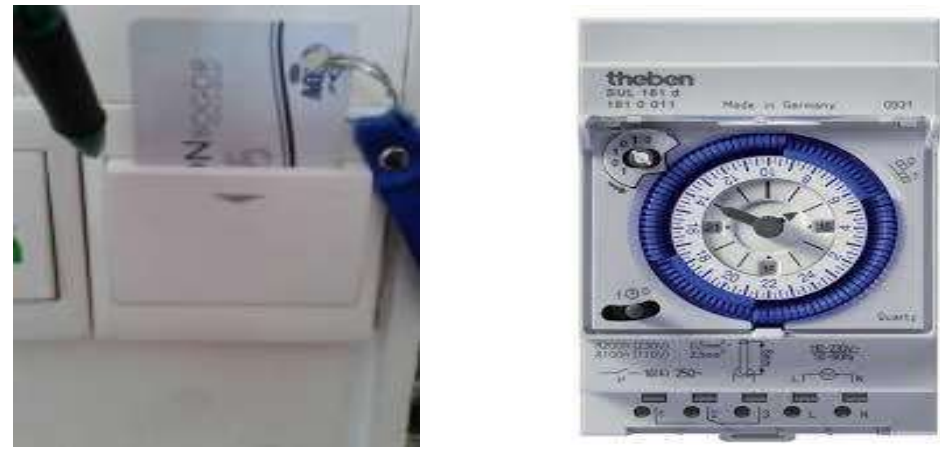

Fig. 4. Saving Energy with Automatic Switch\& Saving Energy with AutomaticTimer Source: Hotel Aston Bogor

Using LED lamp is also part of saving energy. LED technology has many advantages such as non-heat and long-lasting. It also contains no hazardous materials like mercury. LED is also a power saver and small in form. Those are diecribed in figure 5.
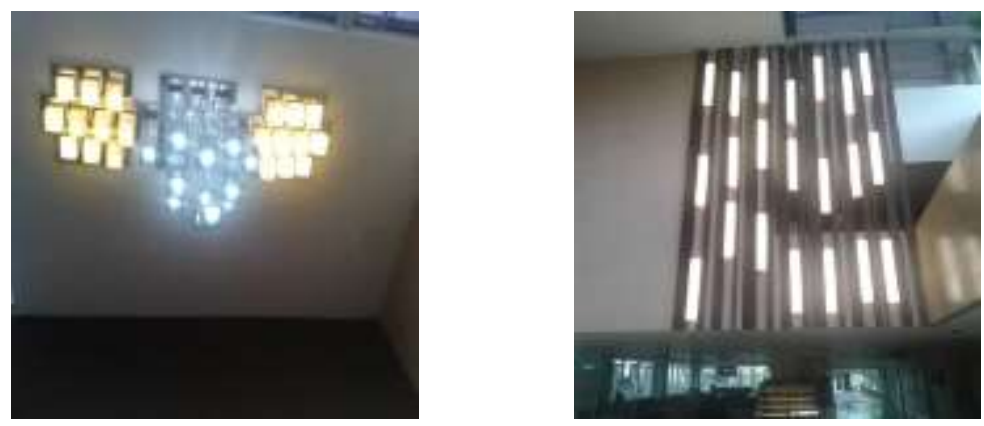

Fig. 5. Saving Energy With LED Lamps Source: Hotel Aston Bogor

Water is a non-renewable natural resource, so its use needs a wise attention. The source of clean water used for both quality and quantity must be adequate without causing environmental damage. Clean water in the hospitality industry, is needed to prepare food, cleaning or hygiene, user comfort, and also for recreation suggestions. 
Raw water sources that can be utilized for the hospitality industry can come from springs, lakes, rivers, or even from sea water according to the needs and the conditions of the surrounding area. Hotels can also use appropriate technology for processing water if the location is not available for water supply from the drinking water company.

Water efficiency policy is applied by Aston Hotel \& Resort Bogor by arranging water valve so that the water debit is not too heavy and it can also be used for managing liquid waste to water the plants safely. It's described in figure 6.

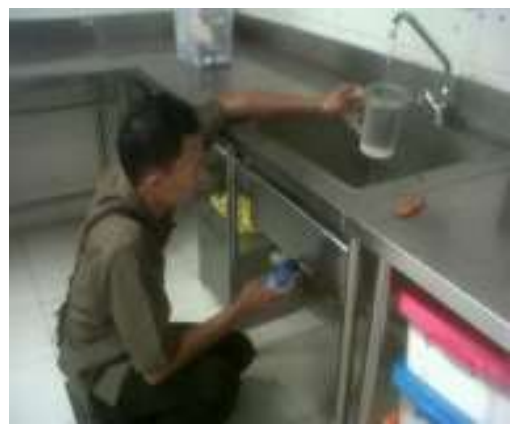

Fig. 6. Saving Energy by Stoping Water Valve Source: Hotel Aston Bogor

In conducting preventive and corrective measures against health-related users, the "Green Team" in a hotel management must perform a monitoring and supervisory system on the building performance, so the results can be used as a basis in making further correction. The monitoring and supervision should involve the users such as the employees, guests, and hotel visitors who are as the most appropriate biological indicator in this case.

The air quality control policy undertaken by Aston Hotel \& Resort Bogor maximizes the air vents. Thus, the cool air in Bogor can be enjoyed in all rooms and it reduces the use of air conditioners. It's described in figure 7.
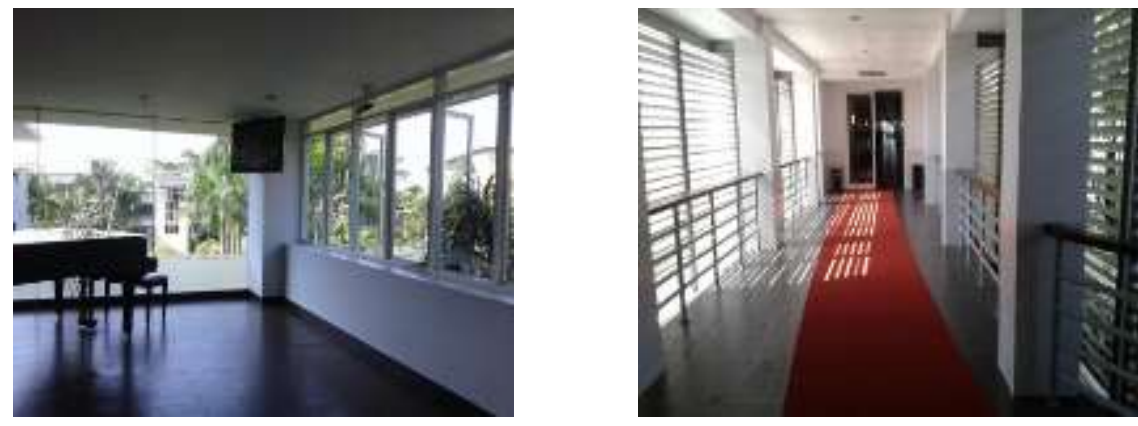

Fig. 7. Maximizing Air Vents Source : Hotel Aston Bogor

The management of liquid waste is needed to maintain the health of hotel users (all residents and managements), where all water sources must be processed in accordance with the Decree of the Minister of Environment no. 52 Year 1995 on the quality standard of liquid waste for hotel activities, and the regulation from Minister of Environment No.5 Year 2011 on the PROPER assessment in environmental management.

Waste management policy conducted by Aston Hotel \& Resort Bogor is processing the liquid waste using aeration system and decomposition bacteria which are environment friendly so it is safe to use for watering plants. The picture of Processing Liquid Waste so it is save for watering the plants is described in figure 8 . 


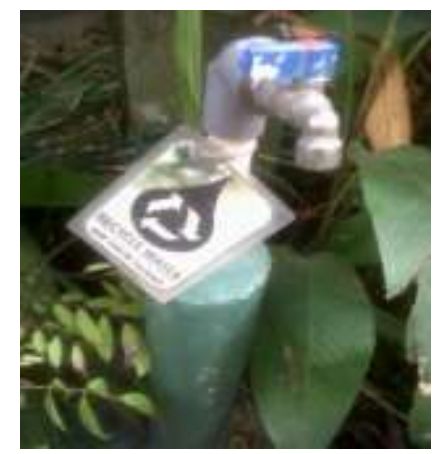

Fig. 8. Processing Liquid Waste so it is save for watering the plants Source : Hotel Aston Bogor

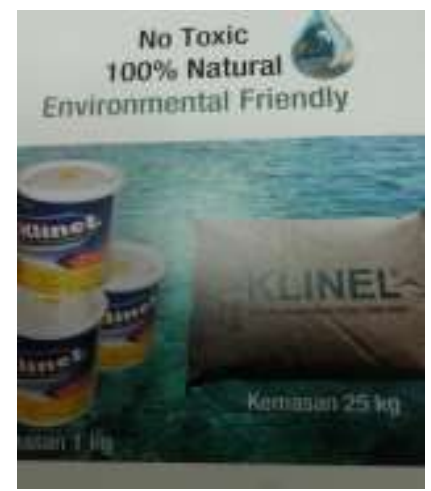

Figure 9. Processing The Liquid Waste Using Aeration System and Decomposition Bacteria which are environment friendly

Source : Hotel Aston Bogor
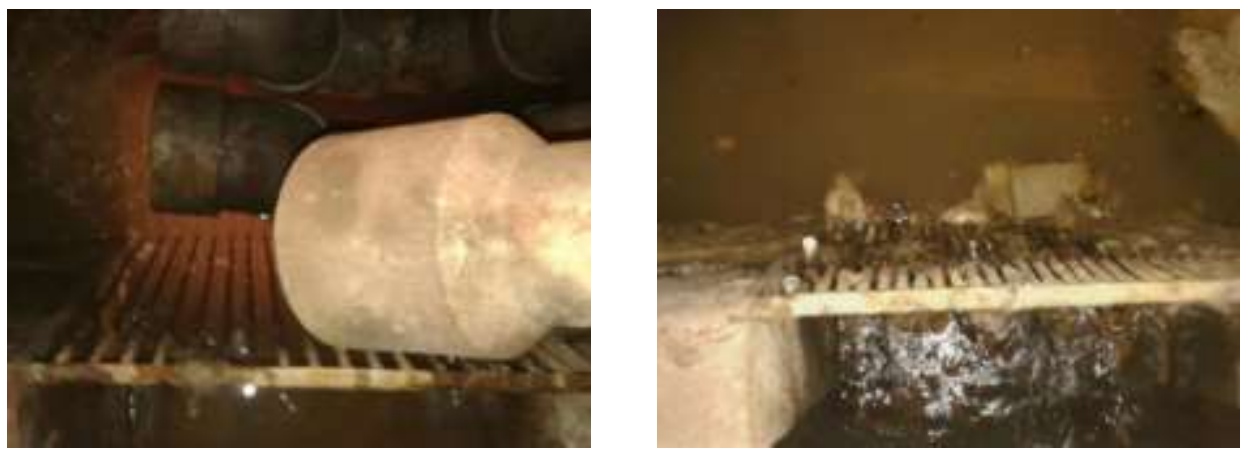

Figure 10. Raw Sewage, Inlet Screen 1 \& Raw Sewage, Inlet Screen 2

Processing the Liquid waste using aeration system and decomposition bacterian which are environment friendly

Source: Hotel Aston Bogor 
B. Policy in improving the quality of human resources, through training according to the competencies required in the fields of energy, water, materials, air, waste, etc.

The policy to improve the quality of human resources (HR) has been done by the Aston Hotel \& Resort Hotel through training to employees in the energy saving department so hotel employees can apply it in daily operations. For example, the employees without excessive goods are expected to use the stairs instead of elevator; the employees are expected to use water efficiently in hotel, etc.
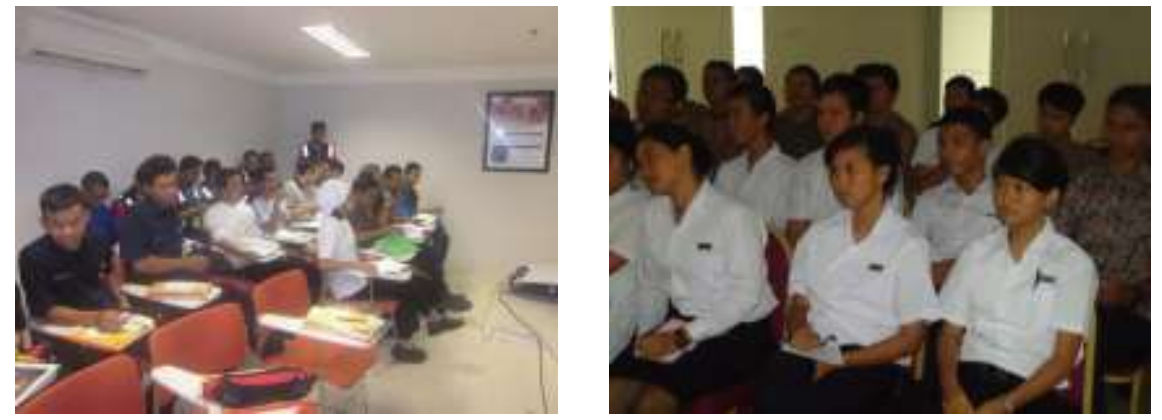

Figure 11. Saving Energi Training

Source: Hotel Aston Bogor

\section{Policies in implementing "Green Hotel" program for hotel staff, guests, and community.}

Aston Hotel \& Resort Hotel puts Green campaign posters in visible places using bilingual languages; Indonesian and English. The campaign describes energy efficiency such as water and electricity. For example, guests who spend more than a day are asked whether they want to reuse bed linen and towels or they want to replace the linen and towels daily. The hotel also puts some Green stickers in employee area, public toilet, bedroom and guest room.

The hotel provides several garbage bins with clear marks to ensure that the garbage is placed according to its type in proper quantities.

Furthermore, the hotel involves the surrounding community actively in the green implementation and reforestation for local environment. Some "No Smoking" stickers are also put inside the hotel building and an open smoking place for guests is provided. Employees are urged to obey the Green rules.

\section{Policies related to social, economic and cultural aspects in society.}

Aston Bogor \& Resort Hotel empowers the local community to fill the needs of the hotel employment by prioritizing to hire applicants from the surrounding community. The hotel also strives to avoid any violation regarding norms, religion, and local customs.

\section{E. Land use policy for any available land according to the land use regulation.}

Nice open landscapes including green open areas, parks, gardens, courtyard, and parking area can be useful and valuable facilities that can help visitors to experience an unforgettable stay at a hotel.Aston Hotel \& Resort Bogor has a green open space, parks, and gardens so guests who stay can enjoy the green open space in their holiday and have a pleasant stay. Aston Hotel \& Resort also has a spacious parking area for hotel guests. 

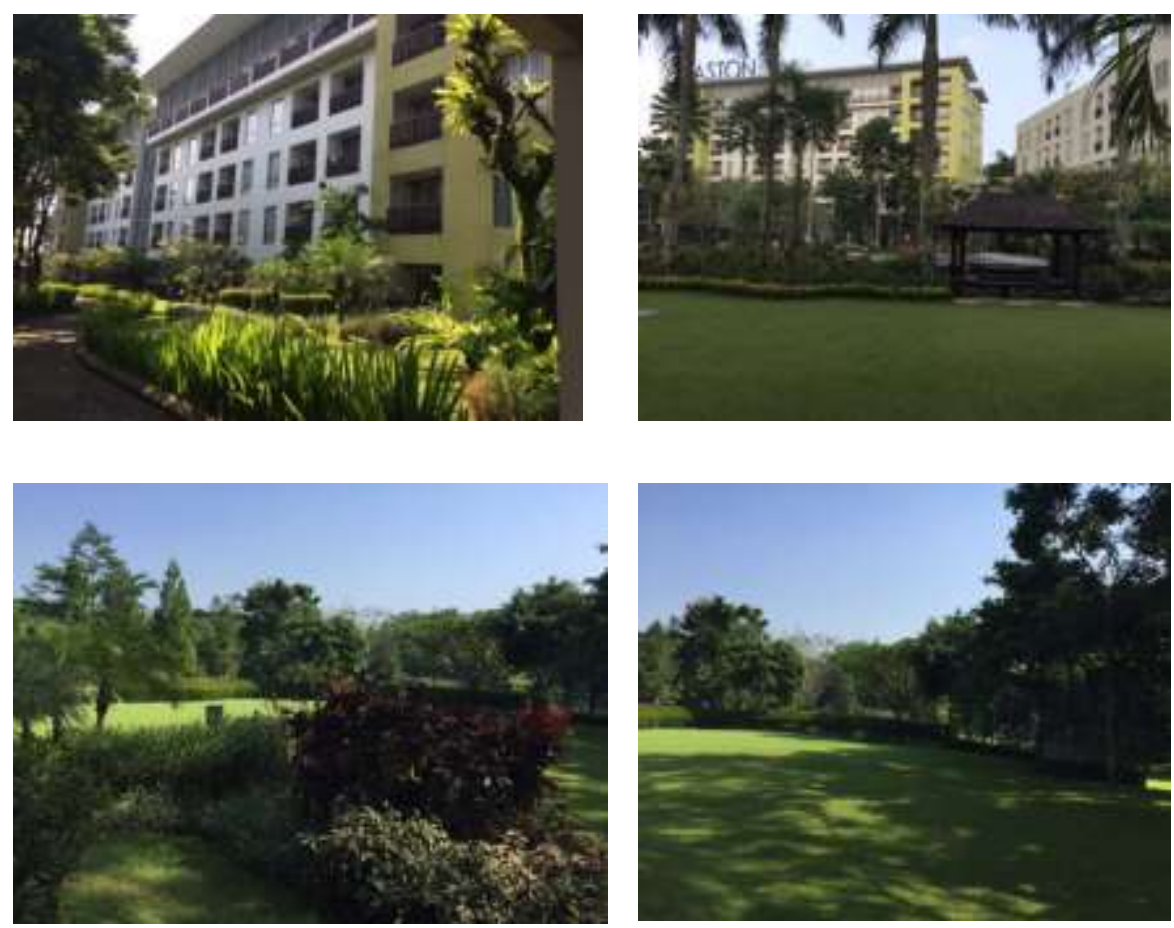

Figure 12. Utilization of available land in accordance with Land Use Policy referring to the regulation Source: Private document

\section{F. Occupational safety and health policy.}

The implementation of occupational safety and health policy aims to create a worker's safety and health system by involving elements of management, labor, and work environment in order to prevent and reduce accidents and diseases caused from work, and create safe, efficient and productive work places.

Aston Hotel \& Resort Hotel has provided information to every staff about various dangers in the workplace which can cause safety and health problems, including fire hazard and how to handle it during the hotel employees training.

\section{G. Hygiene and sanitation policy, especially in food and beverage management.}

Handling food safety is a requirement for the hotel management especially hotels with green concept. Managing food security is an integral part of hygiene sanitation management and should be done properly, correctly and consistently.

Aston Hotel \& Resort Hotel has implemented Hygiene and Sanitation policy, especially for food and beverage management. This sector provides sanitation facilities, such as providing:

1. clean water to process food and beverages for hotel guests,

2. washing equipment and groceries,

3. good waste disposal to avoid food spoilage,

4. trash cans to dispose of food scraps,

5. hand-washers for kitchen employees who process food and beverages,

6. lockers for hotel employees,

7. toilets for hotel employees

\section{H. The implementation of Green Hotel concept policy at Aston Hotel \& Resort Bogor to hotel network management: Neo Hotel + Green SavanaSentul City and Fave Hotel.}

The implementation of green hotel concept policy at Aston Hotel \& Resort Bogor to hotel network management such as Neo Hotel \&Fave Hotel should pay attention to the following matters:

1. All organizational units prepare action plans according to their sectors. 
Aston Hotel \& Resort Bogor plays a major role in helping Neo Hotel and Green Savana-Sentul City to develop action plans in their implementation of green hotel concept policies. Based from its location, Neo Hotel and Green Savana-Sentul City are blessed with a cool air and surrounded by trees, so that the hotel can apply Green Hotel concept in its operational. And so does Fave Hotel, a budget hotel from Archipelago network management, which is expected to have the concept of a budget hotel but still apply the concept of green hotel in its daily operations in order to achieve a more sustainable and environmentally friendly hotel.

2. Team members are given the flexibility to present ideas and to give constructive suggestions for successful environmental conservation activities.

The development of hotel operations with Green Hotel concept needs a special "Green Team" or "Eco Team" which focuses solely on doing 'green/eco' activities. These Green Team members are given the flexibility of deliver ideas and suggestions because every hotel has a different theme although it is under the same management network, for example, the Archipelage management network.

Aston Hotel \& Resort Bogor has Green Team that works on shaping the Green Hotel concept and applies the establishment to management network like Neo Hotel, Green Savana -Sentul City and Fave Hotel to form hotels that have an environmental awareness.

3. Funding support from the hotel management.

Because of the high cost in running the implementation of Green Hotel concept, the hotel management must provide special funds to support the planned activities. Funds prepared are decided based from the star of the hotel. For instance, Aston Hotel \& Resort Bogor has to deal with many policies such as energy efficiency policies, water efficiency policies, waste management policies, etc. To deal with these policies, a large fund is required so forming a green hotel concept at Neo Hotel + Green Sava-Sentul City and Fave Hotel needs full management support to form a real green hotel. The longer term impact is expected be useful for the hotel management.

4. Team members perform activities according to the plans.

After the formation of Green Team, the team must perform its activities according to the plan that has been agreed upon. Aston Hotel \& Resort Bogor and Archipelago management network (Neo Hotel + Green Sava-Sentul City and Fave Hotel) work together in forming the Green Team and the planned activities for the hotel. They need to carry out activities according to the plans to achieve the expected goals. The Aston Hotel Bogor and Resort also supports in providing data on previous activities that have been done in establishing the "Green Hotel" team and providing the implementation steps of these activities.

5. The hotel's managers conduct regular monitoring and supervision of the activity process.

Besides Aston Hotel \& Resort Bogor, the hotel managers of Neo Hotel + Green Sava-Sentul City and Fave Hotel play a major role in monitoring and supervising the green concept building process regularly. The hotel managers must also understand the concept of green hotel so they can picture out the working condition and achieve the goal together with the Green Team and other staff.

6. All Team members are involved in monitoring and supervising the work and are required to immediately report to the experts if finding problems that require further settlement.

Not only Aston Hotel \& Resort Bogor, but all team members should also be involved in monitoring and supervising the work. For example, if in the real practice, there are still many who do not follow the regulation made by Go Green team; it is necessary to have another approach to these people in order for them to follow the rules that apply when shaping the Green Hotel concept. This process can be done by Neo Hotel + Green Sava-Sentul City and Fave Hotel.

7. Problem solving is conducted as soon as possible.

In forming the concept of Green Hotel in Neo Hotel + Green Sava-Sentul City and Fave Hotel, the management needs to take action immediately to solve the problem if the problems inhibit the formation of green concept. The objective is only to ensure that Green Hotel concept can be realized according to 
the expectation from the hotel management. Obstacles or problems will be found because to implement the green concept needs the awareness from each individual who has the same mission and vision.

\section{V.CONCLUSION}

In summary, Aston Hotel \& Resort Bogor has implemented Green Hotel policy made by the Ministry of Tourism of the Republic of Indonesia. There are fourteen aspects of Green Hotel's policy and out of the fourteen aspects, Aston Hotel \& Resort Bogor has implemented energy efficiency policy, water efficiency policy, room ventilation, emission and noise quality policy, waste management policies, appropriate land use policy, human resource quality policy through training, "Green Hotel" implementation program policy for staff-guest-society, occupational health and safety policy, hygiene and sanitation policy especially food and beverage department. However, there are aspects, which have not been done by Aston Hotel \& Resort Bogor, so they still need to be done to meet the Green Hotel concept.

The implementation of green hotel concept policy at Aston Hotel \& Resort Bogor to hotel network management such as Neo Hotel Neo Hotel + Green Savana-Sentul City \&Fave Hotel, goes through several planned activities. First, all organizational units prepare action plans according to their sectors. Second, team members are given the flexibility to present ideas and to give constructive suggestions for successful environmental conservation activities. Third, the hotel management should support the funding financially. Fourth, team members should perform activities according to the plans that have been agreed upon. Fifth, the hotel's managers must conduct monitoring and supervision of the activity process regularly. Sixth, all team members involved in forming the Green Hotel concept must monitor, supervise the work and are required to immediately report to the experts if finding problems that requires further settlement. In the end, the management must solve the problem as soon as possible. These steps are provided to lead the hotel forming and establishing the Green Hotel concept that aims to environmental awareness and sustainability.

\section{REFERENCES}

Anggita.D, Wardhani.A, Danusastro.Y. PenilaianAspek Green Hotel KelasMenengah.MODUL vol 16 No.1 (2016).

Arikunto. S. ProsedurPenelitiansuatupendekatanPraktek. Jakarta BinaAksara. (1986).

Erlangga.T.F.,Rahmafitria.F., Rosita. AnalisisPerbandinganTamuMancanegaradenganTamu Nusantara Terhadap Hotel yang berkonsep Green Hotel Di Kota Bandung.JunalManajemen Resort dan Leisure Vol.13, No.2 (2016).

Industriperhotelandantrenpariwisata di Indonesia.enciety.com.

Nawawi. H.H. ManjemenSumberDayaManusia.EdisiRevisBumiAksara, Jakarta. (2003).

Panduan dan Pedoman Pelaksanaan Green Hotel di Indonesia.KementerianPariwisataRepublik Indonesia (2015-2016).

Penyelenggaraan National Green Hotel Award 2013.https://blog.gbcindonesia.org/penyelenggaraannational-green-hotel-award-2103.html.

Rahmafitria.F. Eco-Resort dan Green Hotel Di Indonesia: Model SaranaAkomodasi yang berkelanjutan. JurnalManajemen Resort \& Leisure Vol.11, No.2 (2014).

Sinangjoyo.N.J. Green Hotel sebagaidayasaingsuatudestinasi.JurnalNasionalPariwisata Vol.5 No.2 (83-93) (2014).

Syahriyah. D.R..PenerapanAspek Green Material padakriteriabangunanramahlingkungan di Indonesia. Prosidingtemuailmiah IPLBI (2016). 